\title{
Performa Inhibitory Control dengan Induksi Sing-a-Song Stress Test pada Dewasa Awal
}

\author{
Akhmad Kurniawan $^{1}$ E Sri Kusrohmaniah ${ }^{2}$ \\ 1,2Fakultas Psikologi Universitas Gadjah Mada
}

\begin{abstract}
Inhibitory control is able to control attention by inhibiting internal tendencies and external influences. Inhibitory control is controlled by dorsolateral prefrontal cortex and anterior cingulate cortex, that can be affected by stress variable. Sing-a-Song Stress Test (SSST) is a current method to induce stress that has never been practiced in study of inhibitory control. This study aimed to determine the effect of SSST against inhibitory control in early adult. Between subjects design was applied in this study. A number of 35 participants with age range from 17 to 21 years old were randomly assigned into experimental group $(n=17)$ and control group $(n=18)$. Inhibitory control was measured using Computerized Stroop Color-Word Test (CSCWT). Positive Affect and Negative Affect Schedule (PANAS) was used to conduct a manipulation check. IndependentSamples T Test explained no significant effect of stress on inhibitory control $(t=-0,117 ; p>$ $0,05)$.
\end{abstract}

Keywords: anterior cingulate cortex; dorsolateral prefrontal cortex; inhibitory control; stress; Sing-a-Song Stress Test

\begin{abstract}
Abstrak. Inhibitory control berfungsi untuk mengontrol atensi dengan cara menghambat kecenderungan internal dan pengaruh eksternal. Inhibitory control dikendalikan oleh dorsolateral prefrontal cortex dan anterior cingulate cortex, yang dapat dipengaruhi oleh variabel stres. Sing-a-Song Stress Test (SSST) merupakan metode baru dalam induksi stres yang belum pernah diterapkan pada penelitian inhibitory control. Penelitian ini bertujuan untuk mengetahui pengaruh SSST terhadap inhibitory control pada dewasa awal. Between subjects design digunakan dalam penelitian ini. Sebanyak 35 partisipan berusia 17 sampai 21 tahun dikelompokkan secara acak ke dalam kelompok eksperimen $(n=17)$ dan kelompok kontrol $(n=18)$. Inhibitory control diukur melalui Computerized Stroop Color-Word Test (CSCWT). Positive Affect and Negative Affect Schedule (PANAS) digunakan untuk melakukan cek manipulasi. Independent-Samples $T$ Test menunjukkan adanya pengaruh yang tidak signifikan antara stres dan inhibitory control $(\mathrm{t}=-0,117 ; \mathrm{p}>0,05)$.
\end{abstract}

Kata kunci: anterior cingulate cortex; dorsolateral prefrontal cortex; inhibitory control; stres; Sing a-Song Stress Test

Fungsi eksekutif merupakan bagian dari proses kognitif yang terjadi pada setiap individu. Burgess dan Alderman (2004) mendefinisikan fungsi eksekutif sebagai

\footnotetext{
${ }^{1}$ Korespondensi mengenai artikel ini dapat melalui:
akhmad.kurniawan@mail.ugm.ac.id, atau

${ }^{1}$ Korespondensi mengenai artikel ini dapa
akhmad.kurniawan@mail.ugm.ac.id, atau

${ }^{2}$ koes_psi@ugm.ac.id
}

kemampuan individu untuk menentukan tujuan, membuat cara-cara untuk mencapai keberhasilan, serta mengikuti dan mengadaptasi langkah-langkah tersebut untuk menghadapi tuntutantuntutan dan perubahan kondisi dalam waktu yang lama. Sementara itu, Iverson, 
Brooks, White, dan Stern (2008) menjelaskan bahwa fungsi eksekutif didefinisikan sebagai kemampuan dan perilaku neurokognitif yang membutuhkan langkahlangkah lebih dari biasanya. Hal ini dilakukan dengan cara melakukan perubahan, menghambat kecenderungan internal, dan melakukan pertimbangan sebelum bertindak (Diamond, 2013).

Diamond (2013) menjelaskan bahwa salah satu komponen penting dalam fungsi eksekutif adalah inhibitory control. Inhibitory control didefinisikan sebagai kemampuan untuk menghentikan atau mengesampingkan suatu proses mental, baik secara keseluruhan maupun hanya sebagian, dengan atau tanpa intensi (MacLeod, 2007). Diamond (2013) mendefinisikan inhibitory control sebagai kemampuan individu dalam mengontrol atensi, perilaku, pikiran, dan/atau emosi untuk mengesampingkan kecenderungan internal atau pengaruh eksternal yang kuat, serta melakukan tindakan yang tepat atau dibutuhkan. Sementara itu, MacLeod (2007) mendefinisikan inhibitory control sebagai kemampuan untuk menghentikan atau mengesampingkan suatu proses mental, baik secara keseluruhan maupun hanya sebagian, dengan atau tanpa intensi.

Inhibitory control terdiri dari tiga aspek, yaitu attention inhibition, cognitive inhibition, dan self-control (Diamond, 2013). Attention inhibition berkaitan dengan proses penghambatan stimulus yang mendistraksi fokus sedangkan cognitive inhibition berkaitan dengan proses penghambatan proses kognitif yang tidak relevan (Diamond, 2013). Self-control berkaitan dengan penghambatan respon motorik individu (Diamond, 2013).

Inhibitory control melekat pada fenomena selective attention, yang merupakan kondisi fokus individu pada suatu informasi di antara banyaknya informasi yang diterima (MacLeod, 2007). Informasiinformasi yang diterima individu digambarkan seperti kurva distribusi berbentuk lonceng (MacLeod, 2007). Stimulusstimulus yang mendekati titik pusat merupakan informasi target sehingga stimulus tersebut mendapatkan atensi yang lebih banyak dan pemrosesan informasi yang lebih cepat. Semakin jauh dari titik pusat, informasi tersebut semakin tidak relevan. Informasiinformasi tidak relevan ini akan diabaikan oleh individu. Proses mengesampingkan informasi ini disebut sebagai inhibitory control (MacLeod, 2007).

Inhibitory control dapat digambarkan seperti perilaku pengendara sepeda motor. Pengendara sepeda motor melakukan selective attention terhadap kondisi jalan raya. Pengendara berfokus pada situasi jalan agar ia tidak menabrak pengendara lainnya. Pengendara sepeda motor juga melakukan inhibitory control pada stimulus-stimulus yang mendistraksi perhatian, misalnya baliho-baliho iklan yang terpasang di sebelah kiri dan kanan jalan. Tanpa inhibitory control yang baik, pengendara akan mudah terpengaruh oleh distraksi-distraksi yang mengganggu selective attention.

Inhibitory control dapat diukur dengan menggunakan Stroop-Color Word Test. Stroop (1935) telah memperkenalkan alat ukur ini dalam tiga kali eksperimen. Eksperimen ketiga Stroop (1935) merupakan penyempurnaan dari eksperimen pertama dan kedua. Eksperimen ini menyajikan Stroop Color-Word Test dalam bentuk tulisan enam nama warna (merah, biru, hijau, cokelat, ungu, dan putih) yang dicetak pada kertas persegi berwarna hitam. Warna-warna tersebut diacak untuk menghindari kemunculan sama yang berulang-ulang. Setiap warna hanya 
muncul dua kali pada setiap kolom dan setiap baris. Computerized Stroop-Color Word Test (CSCWT) merupakan pengembangan dari Stroop Color-Word Test (Assef, Capovilla, \& Capovilla, 2007; Pilli, Naidu, Pingali, Shobha, \& Reddy, 2013). CSCWT menyajikan Stroop Color-Word Test dalam bentuk komputerisasi. CSCWT memberikan data waktu reaksi partisipan yang lebih akurat dalam menjawab tugas kongruen dan inkongruen.

Pengukuran inhibitory control yang pernah dilakukan menjelaskan bahwa puncak inhibitory control terjadi pada masa dewasa awal (Christ, White, Mandernach, \& Keys, 2001). Masa dewasa awal memiliki rentang usia antara 17 sampai dengan 45 tahun (Levinson, 1986). Christ, et al. (2001) menambahkan bahwa masa kanak-kanak dan dewasa akhir memiliki inhibitory control yang lebih rendah daripada masa dewasa awal. Masa dewasa akhir merupakan rentang usia dengan inhibitory control yang paling rendah.

Salah satu faktor yang dapat memengaruhi inhibitory control adalah stres. Hal ini disebabkan karena inhibitory control dikendalikan oleh dorsolateral prefrontal cortex dan anterior cingulate cortex (MacLeod, 2015). Bagian saraf pusat ini rentan terpengaruh oleh kondisi stres (Roos, et al., 2017; Dierolf, Fechtner, Bohnke, Wolf, \& Naumann, 2017).

Selye (1974) mendefinisikan stres sebagai respon adaptif tubuh terhadap tuntutan-tuntutan yang dihadapi individu. Sementara itu, Lazarus (1999) mendefinisikan stres sebagai situasi tidak menyenangkan, yang dapat berubah dengan cepat dan ingin diubah oleh individu. Selye (1974) membedakan stres ke dalam dua dimensi, yaitu eustress dan distress. Eustress diasosiasikan sebagai kondisi stres yang bersifat konstruktif sedangkan distress diasosiasikan sebagai kondisi stres yang bersifat destruktif (Selye, 1974).

Penelitian-penelitian sebelumnya telah menjelaskan pengaruh stres terhadap inhibitory control. Lyons, Lopez, Yang, dan Schatzberg (2000) menjelaskan bahwa peningkatan cortisol pada dopamine neurotransmitter yang ada di prefrontral cortex dapat menurunkan inhibitory control. Roos, et al. (2017) juga menjelaskan bahwa stres dapat menurunkan inhibitory control. Penurunan aktivitas Parasympathetic Nervous System (PNS) dapat memprediksi inhibitory control yang lebih baik sedangkan peningkatan aktivitas PNS dihubungkan dengan rendahnya inhibitory control.

Berbeda dengan penelitian yang dipaparkan sebelumnya, penelitian yang dilakukan oleh Schwabe, Höffken, Tegenthoff, dan Wolf (2013) menunjukkan bahwa stres dapat meningkatkan inhibitory control. Pengaruh tersebut difasilitasi oleh fungsi Mineralocorticoid Receptors (MR). Dierolf, et al. (2017) juga menunjukkan bahwa stres dapat meningkatkan inhibitory control dan conflict monitoring.

Penelitian mengenai pengaruh stres terhadap inhibitory control sebelumnya dilakukan dengan cara menginduksikan stres pada partisipan penelitian. Sing- $a$ Song Stress Test (SSST) merupakan metode induksi baru yang dapat diterapkan dalam pengaturan eksperimen. SSST berpedoman kuat pada standar etika karena SSST dilakukan dengan tidak meminta partisipan untuk memakan dan meminum sesuatu atau melakukan aktivitas fisik tertentu dalam memunculkan respon stres (Brouwer \& Hogervorst, 2014). Belum ada penelitian yang mengungkap pengaruh stres terhadap inhibitory control dengan menggunakan induksi SSST. Penelitian ini bertujuan untuk mengetahui pengaruh stres dengan induksi SSST terhadap 
inhibitory control pada dewasa awal yang diukur dengan menggunakan CSCWT.

\section{Metode}

\section{Partisipan}

Total partisipan yang mengikuti penelitian ini adalah 35 partisipan, yang terdiri dari 27 perempuan dan 8 laki-laki. Partisipan penelitian memiliki rata-rata usia 18,9 tahun. Partisipan penelitian dikelompokkan secara acak ke dalam kelompok eksperimen dan kelompok kontrol. Sebanyak 17 partisipan, yang terdiri dari 12 perempuan dan 5 laki-laki, dikelompokkan ke dalam kelompok eksperimen. Partisipan kelompok eksperimen memiliki rata-rata usia 18,9 tahun. Partisipan kelompok kontrol berjumlah 18 partisipan, yang terdiri dari 15 perempuan dan 3 lakilaki. Rata-rata usia kelompok kontrol adalah 18,8 tahun.

\section{Material}

Sing-a-song stress test

Induksi stres diberikan dengan menggunakan Sing-a-Song Stress Test (SSST; Brouwer \& Hogervorst, 2014). Layar komputer menampilkan pesan perintah bernyanyi atau pesan netral SSST (Brouwer \& Hogervorst, 2014) yang telah diterjemahkan ke dalam bahasa Indonesia. Alih bahasa bertujuan agar partisipan, yang seluruhnya menggunakan bahasa Indonesia dalam aktivitas keseharian, dapat memahami instruksi. Peneliti berada di dalam ruang eksperimen selama penelitian berlangsung sebagai bentuk social stressor.

Partisipan kelompok eksperimen mendapatkan pesan perintah bernyanyi: "Nyanyikan lagu dengan keras ketika penghitung menunjukkan angka nol. Tetap duduk diam sampai layar menun- jukkan angka nol." Layar menampilkan hitungan mundur 60 detik setelah pesan perintah bernyanyi diberikan. Partisipan kelompok kontrol mendapatkan tampilan pesan netral Brouwer dan Hogervorst (2014): "Alat penyedot debu pertama kali diciptakan oleh Sweep Company. Alat ini diciptakan tahun 1907 dengan nama hoover." Selanjutnya, layar menampilkan pesan-pesan: "Silakan tunggu instruksi berikutnya." selama 60 detik.

\section{Computerized stroop color-word test}

Pengukuran inhibitory control dilakukan dengan menggunakan Computerized Stroop Color-Word Test (CSCWT). CSCWT merupakan bentuk komputerisasi dari Stroop Color-Word Test (Stroop, 1935). Dalam penelitian ini, CSCWT didesain dengan memunculkan 120 kali tulisan "merah", "hijau", dan "biru" yang ditampilkan dalam warna merah, hijau, atau biru. Setiap warna muncul dalam 20 kali kata kongruen dan 20 kali kata inkongruen. Kata kongruen merupakan tulisan yang ditampilkan dalam warna yang sesuai dengan nama warna tersebut, misalnya kata "merah" ditampilkan dalam warna merah dan kata "hijau" ditampilkan dalam warna hijau. Kata inkongruen merupakan tulisan yang ditampilkan dalam warna yang berbeda dengan nama warna tersebut, misalnya kata "biru" ditampilkan dalam warna merah dan kata "merah" ditampilkan dalam warna hijau. Warna-warna tersebut ditampilkan secara acak untuk menghindari kemunculan warna sama yang berulang-ulang. Oleh karena itu, setiap kata kongruen dan inkongruen hanya muncul maksimal tiga kali berturut-turut dalam kata dan warna yang sama.

Partisipan diminta untuk menentukan warna tampilan kata dengan mengabaikan tulisan nama warna yang tertera. 
Perhitungan inhibitory control dilakukan dengan cara mencari selisih antara ratarata waktu reaksi kongruen dan rata-rata waktu reaksi inkongruen (MacLeod, 2015). Hasil dari perhitungan tersebut adalah skor interference.

CSCWT dalam penelitian ini disajikan dengan menggunakan program komputer PsychoPy v1.8. PsychoPy merupakan program yang dikembangkan oleh Pierce di laboratorium University of Nottingham. Pierce (2007) dalam jurnalnya menyatakan bahwa PsychoPy didesain untuk mengumpulkan data respon berdasarkan penyajian alat ukur psikologi, neurosains, dan psikofisik berbasis komputer untuk dianalisis secara psikometris. PsychoPy $v 1.8$ diunduh secara gratis melalui alamat web resmi PsychoPy.

Pengumpulan data waktu reaksi pada program PsychoPy v1.8 diintegrasikan dengan pengumpulan data alat lain, yaitu mikrofon dan kamera. Data yang berasal dari mikrofon dan kamera digunakan sebagai data observasi penelitian. Program yang digunakan untuk mengintegrasikannya adalah iMotions 1.0.

\section{Positive affect and negative affect schedule}

Cek manipulasi (manipulation check) dilakukan dengan menggunakan Skala Positive Affect and Negative Affect Schedule (PANAS) (Watson, Clark, dan Tellegen, 1988). Skala PANAS yang digunakan dalam penelitian ini telah diadaptasi dan diterjemahkan ke dalam bahasa Indonesia oleh Utami (2010). Skala PANAS terdiri dari Subskala Afek Positif dan Subskala Afek Negatif. Skala PANAS dijawab dengan menggunakan 5 alternatif nilai, yang bergerak dari 1 sampai dengan 5 . Skor terendah sampai tertinggi pada Skala PANAS adalah 1 (afek sangat sedikit), 2 (afek sedikit), 3 (afek normal), 4 (afek cukup banyak), dan 5 (afek sangat banyak) dirasakan partisipan.

Bagian dari Skala PANAS yang dapat digunakan untuk mengonfirmasi tingkat stres partisipan penelitian adalah Subskala Afek Negatif (Schoofs, Preuß, \& Wolf, 2008; Echterhoff \& Wolf, 2012). Watson dan Clark (1984) menjelaskan bahwa afek negatif merepresentasikan kondisi distress, ketidaknyamanan, dan ketidakpuasan dalam diri individu. Penelitian yang dilakukan oleh Watson, et al. (1988) menunjukkan bahwa hasil pengukuran Subskala Afek Negatif berkorelasi positif dengan hasil pengukuran Hopkins Symptom Checklist (HSCL), Beck Depression Inventory (BDI), dan STAI State Anxiety Scale (A-State).

Tingkat stres partisipan penelitian diketahui dengan cara menjumlahkan semua respon pada butir-butir Subskala Afek Negatif. Kondisi ini diukur berdasarkan penyajian 10 kata sifat yang menggambarkan afek negatif: sedih, marah, bermusuhan, mudah marah, takut, khawatir, malu, bersalah, gugup, dan gelisah (Utami, 2010). Schoofs, et al. (2008) dan Echterhoff dan Wolf (2012) menyatakan bahwa skor afek negatif yang tinggi merepresentasikan tingkat stres yang tinggi. Sebaliknya, tingkat stres yang rendah ditunjukkan dengan skor afek negatif yang rendah (Schoofs et al., 2008; Echterhoff \& Wolf, 2012).

Uji konsistensi internal pada Subskala Afek Negatif menunjukkan bahwa semua butir memiliki total-item correlation yang baik $(r=0,343$ - 0,800). Azwar (2015) mengatakan bahwa uji reliabilitas dapat dilakukan dengan menggunakan formula koefisien alpha $(\alpha)$. Koefisien Cronbach's Alpha menunjukkan nilai 0,951 sehingga Subskala Afek Negatif dalam penelitian ini memiliki reliabilitas yang tinggi. 
Subskala Afek Positif juga dianalisis dalam penelitian ini. Skor afek positif partisipan digunakan untuk mendapatkan gambaran emosi partisipan secara integratif. Subskala Afek Positif mengukur afek positif partisipan berdasarkan 10 kata sifat positif yang menggambarkan afek positif: perhatian, tertarik, waspada, bersemangat, antusias, terinspirasi, bangga, kuat, dan aktif (Utami, 2010). Jumlah respon partisipan pada semua butir Subskala Afek Positif menghasilkan skor afek positif (Utami, 2010).

Uji konsistensi internal pada Subskala Afek Positif menunjukkan bahwa 11 butir memiliki total-item correlation yang rendah $(r<0,300)$ sehingga sebanyak 11 butir Subskala Afek Positif digugurkan dari analisis. Sebanyak 16 butir Subskala Afek Positif dengan total-item correlation yang baik $(r=0,320-0,720)$ digunakan dalam analisis data. Koefisien Cronbach's Alpha pada 16 butir Subskala Afek Positif menunjukkan nilai 0,873 .

\section{Prosedur}

Pengambilan data dilaksanakan dalam 8 hari sesuai dengan kesediaan partisipan dan sumber daya penelitian. Eksperimen berlangsung selama 15 sampai 30 menit untuk setiap sesinya. Setiap partisipan diminta untuk datang ke ruang tunggu eksperimen sesuai dengan jadwal yang telah disepakati. Partisipan dipersilakan untuk pergi ke toilet sebelum masuk ke ruang eksperimen. Peneliti membawa partisipan (berjumlah satu orang) dari ruang tunggu menuju ruang eksperimen setelah partisipan mengisi lembar presensi. Peneliti memperkenalkan diri dan menjelaskan tujuan penelitian. Partisipan diminta untuk duduk tenang dan tetap melihat ke layar selama menjalani sesi eksperimen. Peneliti mempersilakan partisipan untuk mengajukan pertanyaan jika ada hal yang belum dipahami.

Peneliti menjalankan program iMotions 1.0 dan mengisikan identitas partisipan pada program tersebut. Peneliti menekan tombol "start" ketika partisipan telah siap menjalani eksperimen. Partisipan mendapatkan perlakuan eksperimen atau perlakuan kontrol SSST sesuai dengan pembagian kelompok. Semua partisipan selanjutnya mengerjakan Computerized Stroop Color-Word Test (CSCWT). Peneliti menekan tombol "end" di layar komputer setelah partisipan menyelesaikan CSCWT. Peneliti meminta partisipan untuk mengisi skala Positive Affect and Negative Affect Schedule (PANAS). Terakhir, peneliti memberikan debriefing dalam bentuk penjelasan tentang eksperimen yang telah dilakukan dan pemberian tanda terima kasih.

Setiap partisipan menjalani eksperimen secara individual di ruangan dengan suhu dan pencahayaan yang sama. Semua jendela telah ditutup untuk mengontrol distraksi-distraksi yang tidak diinginkan. Partisipan juga menggunakan perangkat komputer yang sama, yaitu layar monitor Dell, Microsoft keyboard, serta CPU dengan komponen MSI motherboard dan Intel ${ }^{\circledR}$ processor.

\section{Hasil}

Hasil uji komparasi Independent-Samples $T$ Test menunjukkan adanya perbedaan skor interference yang tidak signifikan antara kelompok eksperimen dan kelompok kontrol $(t=-0,117 ; p>0,05)$. Stres yang diinduksikan melalui SSST tidak berpengaruh signifikan terhadap kemampuan inhibitory control partisipan penelitian.

Cek manipulasi stres dengan menggunakan uji komparasi Independent-Samples $T$ Test juga menunjukkan bahwa kelompok 
eksperimen dan kelompok kontrol memiliki perbedaan skor afek negatif yang tidak signifikan $(t=-1,268, p>0,05)$. Dapat diartikan bahwa kelompok eksperimen dan kelompok kontrol tidak memiliki perbedaan tingkat stres yang signifikan.

Pengelompokkan tingkat stres partisipan dilakukan dengan menggunakan model distribusi normal (Azwar, 2015). Stres partisipan kelompok eksperimen $(x=$ $59,18)$ berada dalam kategori rendah $(x \leq$ $67,67)$ sedangkan stres partisipan kelompok kontrol $(x=67,78)$ berada dalam kategori sedang $(67,67<x \leq 106,3)$.

Uji komparasi juga dilakukan pada skor afek positif. Independent-Samples $T$ Test menampilkan perbedaan skor afek positif pada kelompok eksperimen dan kelompok kontrol yang tidak signifikan $(t$ $=-0,471, p>0,05)$. Oleh karena itu, kelompok eksperimen dan kelompok kontrol tidak memiliki perbedaan afek positif yang signifikan. Pengelompokkan berdasarkan distribusi normal menunjukkan bahwa kelompok eksperimen ( $x=$ $52,94)$ dan kelompok kontrol $(x=54,22)$ berada dalam kategori yang sama. Kedua kelompok memiliki afek positif dalam kategori sedang $(37,33<x \leq 58,67)$.

\section{Diskusi}

Hasil penelitian menunjukkan bahwa stres dengan induksi SSST tidak berpengaruh secara signifikan terhadap inhibitory control pada dewasa awal yang diukur dengan menggunakan CSCWT. Temuan ini bertolak belakang dengan penelitian-penelitian sebelumnya. Lyons, et al. (2000) dan Roos, et al. (2017). Lyons, et al. (2000) dan Roos, et al. (2017) menjelaskan bahwa stres dapat menurunkan performansi inhibitory control. Temuan dalam penelitian ini juga bertolak belakang dengan penelitian Schwabe, et al. (2013) dan Dierolf, et al. (2017) yang menjelaskan bahwa stres dapat meningkatkan inhibitory control.

Hasil yang ditemukan dalam penelitian ini dapat disebabkan karena stres kelompok eksperimen dan kelompok kontrol tidak memiliki perbedaan yang signifikan setelah pemberian perlakuan. Hasil ini bertolak belakang dengan hasil penelitian Brouwer dan Hogervorst (2014) yang menjelaskan bahwa SSST dapat meningkatkan stres partisipan penelitian.

Tingkat stres kelompok eksperimen justru berada dalam kategori rendah sedangkan tingkat stres kelompok kontrol berada dalam kategori sedang. Pengelompokkan ini berkaitan dengan penelitian sebelumnya yang dilakukan oleh Fancourt, Aufegger, dan Williamon (2015) dan Fancourt, Williamon, Carvalho, Steptoe, Dow, dan Lewis (2016). Fancourt, et al. (2015) dan Fancourt, et al. (2016) menjelaskan bahwa aktivitas bernyanyi dapat mereduksi stres. Fenomena ini dinamakan sebagai soothing effect. Meskipun demikian, tingkat afek positif partisipan berbeda dengan hasil penelitian Fancourt, et al. (2016) yang menyatakan bahwa aktivitas bernyanyi dapat memunculkan afek positif. Afek positif kelompok eksperimen dan kelompok kontrol berada dalam kategori yang sama, yaitu kategori sedang. Hasil cek manipulasi juga menunjukkan bahwa partisipan kedua kelompok tidak memiliki perbedaan stres dan afek positif yang signifikan.

Alat ukur CSCWT dalam penelitian ini bias terhadap kondisi stres sehingga kedua kelompok sama-sama mendapatkan pengaruh stres. Hal ini dapat menyebabkan kedua kelompok memiliki perbedaan stres yang tidak signifikan. Karthikeyan, Murugappan, dan Yaacob (2014) telah melakukan penelitian untuk mendeteksi stres partisipan pada saat mengerjakan Stroop Color-Word Test. Penelitian ini 
dilakukan pada 10 partisipan perempuan dengan rentang umur 20 sampai 25 tahun. Electro Cardio Graphy (ECG) dan Heart Rate Variability (HRV) digunakan untuk mengkonfirmasi perubahan stres partisipan. Hasil penelitian menunjukkan bahwa partisipan penelitian mengalami perubahan stres yang signifikan antara kondisi normal dan kondisi eksperimen.

Renaud dan Blondin (1997) juga telah melakukan penelitian mengenai respon fisiologis dan emosional individu terhadap Computerized Stroop Color-Word Test (CSCWT). Partisipan dalam penelitian ini berjumlah 48 individu, yang dibagi ke dalam tiga kelompok penelitian. Partisipan penelitian diminta untuk mengerjakan CSCWT setelah pengambilan data baseline dilakukan. Hasil penelitian menunjukkan bahwa partisipan penelitian mengalami perubahan kecemasan, detak jantung, dan konduksi kulit selama mengerjakan CSCWT. Kondisi partisipan kembali ke kondisi awal setelah partisipan menjalani sesi pemulihan.

Partisipan dalam penelitian ini menjalani eksperimen dalam waktu yang bervariasi. Kesediaan waktu partisipan berbeda-beda tergantung pada jadwal perkuliahan dan aktivitas di luar kuliah. Hal ini juga menjadi salah satu faktor yang memengaruhi hasil penelitian. Data memperlihatkan bahwa jadwal eksperimen paling awal adalah pukul 08.49 WIB dan paling akhir adalah pukul 15.00 WIB. Waktu eksperimen yang berbeda-beda dapat memunculkan efek fatigue pada partisipan-partisipan tertentu. Fatigue merupakan kondisi suboptimal individu yang ditandai dengan penurunan performansi (Phillips, 2015). Phillips (2015) menjelaskan bahwa faktor beban kerja, seperti kuliah yang baru saja dijalani partisipan, dapat memunculkan kondisi fatigue pada partisipan penelitian. Phillips
(2015) juga menambahkan bahwa circadian rythms yang terjadi di dalam tubuh merupakan salah satu faktor yang dapat memunculkan kondisi fatigue. Vitaterna, Takahashi, dan Turek (2001) memaparkan bahwa setiap individu memiliki circadian rythms yang terjadi dalam 24 jam. Kondisi tubuh akan berubah-ubah sepanjang hari sesuai ritme tertentu (Vitaterna et al., 2001). Individu memiliki aktivitas dan performansi yang berbeda-beda pada pagi, siang, sore, dan malam hari.

Penelitian ini memiliki beberapa keterbatasan. Pertama, distraksi-distraksi yang muncul dari pihak tidak berkepentingan yang melewati koridor ruang eksperimen sulit dikontrol. Distraksi tersebut disebabkan karena eksperimen dilaksanakan di sebuah ruangan, yang mana bagian depan ruangan tersebut memiliki koridor yang dapat dilalui oleh pihak umum. Meskipun demikian, Myers dan Hansen (2002) menyatakan bahwa validitas penelitian tetap dapat tercapai. Hal ini disebabkan karena semua partisipan sama-sama mendapatkan extraneous variable yang mendistraksi. Kondisi ini dinamakan sebagai constancy of condition (Myers \& Hansen, 2002). Penelitian selanjutnya sebaiknya melaksanakan eksperimen di ruang yang terbebas dari distraksi.

Pengecekan buta warna belum dilakukan pada partisipan penelitian. Partisipan dengan buta warna dapat mengganggu jalannya eksperimen. Hal ini disebabkan karena CSCWT merupakan alat ukur inhibitory control yang meminta partisipan untuk menyebutkan nama warna dan mengesampingkan tulisan yang tertera di layar komputer. Pengecekan buta warna merupakan prosedur yang penting dilakukan pada penelitian-penelitian berikutnya.

Ketiga, pemilihan CSCWT untuk mengukur inhibitory control partisipan 
dinyatakan kurang tepat. Penelitianpenelitian sebelumnya menjelaskan bahwa CSCWT memiliki dampak terhadap kondisi stres patisipan. Kondisi tersebut menyebabkan adanya kemunculan bias pada variabel independen penelitian. Kedua kelompok dimungkinkan samasama mendapatkan kondisi stres. Penelitian selanjutnya sebaiknya menggunakan alat ukur variabel dependen yang tidak bias terhadap variabel independen.

Penelitian ini hanya menggunakan tiga warna stimulus kongruen dan inkongruen. Penggunaan tiga warna bertujuan agar partisipan penelitian merasa nyaman dalam menggunakan keyboard. Partisipan hanya menggunakan tiga jari yang diletakkan pada tombol arah panah kiri, arah panah bawah, dan arah panah kanan. Penambahan warna dikhawatirkan dapat menyebabkan partisipan sulit menjangkau tombol keyboard sehingga hal ini mempengaruhi hasil penelitian. Pada kenyataannya, penggunaan tiga warna justru dimungkinkan dapat menurunkan tingkat kesulitan CSCWT. Stroop (1935) menggunakan enam warna dalam eksperimen ketiga yang dilakukannya. Penelitian selanjutnya sebaiknya memperhatikan kembali kelemahan ini.

SSST juga tidak mampu meningkatkan stres partisipan penelitian. SSST merupakan metode baru untuk mengondisikan stres partisipan dalam pengaturan eksperimen. Brouwer dan Hogervorst (2014) menjelaskan bahwa SSST dapat digunakan untuk menginduksikan stres partisipan. Meskipun demikian, belum banyak literatur yang menggunakan SSST sebagai metode induksi stres. Belum banyak literatur yang membuktikan efektivitas SSST untuk meningkatkan stres partisipan. Trier Social Stress Test (TSST; Kirschbaum, Pirke, dan Hellhammer, 1993) merupakan alternatif lain yang dapat digunakan untuk menginduksikan stres pada partisipan penelitian.

Baseline kondisi stres belum diukur dalam pelaksanaan eksperimen. Hal ini disebabkan karena prosedur eksperimen mengadaptasi prosedur SSST sebelumnya yang dilakukan oleh Brouwer dan Hogervorst (2014). Brouwer dan Hogervorst (2014) melakukan eksperimen dengan memberikan alat ukur penilaian subjektif sebagai post-test. Meskipun demikian, Brouwer dan Hogervorst (2014) telah mengambil data baseline dengan menggunakan alat ukur respon detak jantung dan respon konduksi kulit. Penelitian ini hanya menggunakan alat ukur penilaian subjektif sebagai instrumen post-test stres. Hal ini menyebabkan perbedaan stres sebelum dan sesudah pemberian SSST tidak dapat diketahui. Hasil penelitian hanya mengonfirmasi adanya perbedaan stres yang tidak signifikan antara kelompok eksperimen dan kelompok kontrol. Penelitian selanjutnya sebaiknya mengukur kondisi baseline respon stres partisipan sehingga perbedaan tingkat stres sebelum dan sesudah pemberian kondisi stres dapat diketahui.

Terakhir, tingkat stres partisipan belum terkonfirmasi melalui alat ukur integratif. Alat ukur penilaian subjektif yang digunakan dalam penelitian ini belum bisa mendeteksi stres partisipan secara real time. Peneliti Sing-a-Song Stress Test (SSST) sebelumnya, Brouwer dan Hogervorst (2014), menggunakan integrasi alat ukur respon detak jantung, respon konduksi kulit, dan penilaian subjektif untuk mendeteksi stres partisipan. Brouwer dan Hogervorst (2014) menemukan bahwa penilaian subjektif memiliki korelasi yang signifikan dengan respon konduksi kulit tetapi tidak memiliki korelasi dengan respon detak jantung (Brouwer dan Hogervorst, 2014). 
Penelitian lain yang dilakukan oleh Renaud dan Blondin (1997) juga menerapkan integrasi penilaian subjektif, respon detak jantung, dan respon konduksi kulit. Renaud dan Blondin (1997) mengintegrasikan ketiga alat tersebut untuk mengukur stres partisipan dalam mengerjakan CSCWT. Sementara itu, Karthikeyan, et al. (2014) melakukan penelitian dengan mengintegrasikan deteksi respon detak jantung dan respon konduksi kulit untuk membandingkan tingkat stres partisipan ketika mengerjakan Stroop Color-Word Test dan tugas kontrol. Integrasi alat ukur psikologi dan fisiologi merupakan metode yang tepat digunakan pada penelitian-penelitian selanjutnya untuk mengetahui stres partisipan secara real time dan akurat.

\section{Kesimpulan}

Berdasarkan hasil dan diskusi penelitian, disimpulkan bahwa stres dengan induksi SSST tidak berpengaruh secara signifikan terhadap inhibitory control pada dewasa awal yang diukur dengan menggunakan CSCWT.

\section{Saran}

Keterbatasan-keterbatasan dalam penelitian ini dapat diperbaiki untuk penelitian selanjutnya dengan melaksanakan eksperimen di ruang bebas distraksi, melakukan penyaringan kelainan buta warna, menggunakan alat ukur variabel dependen yang tidak bias terhadap variabel independen, meninjau kembali penggunaan tiga warna dalam CSCWT, mempertimbangkan metode lain yang lebih efektif untuk menginduksikan stres partisipan seperti Trier Social Stress Test (TSST) atau injeksi kortisol, mengukur kondisi baseline respon stres partisipan sehingga perbedaan tingkat stres sebelum dan sesudah pemberian kondisi stres dapat diketahui, serta menggunakan integrasi alat ukur psikologi dan fisiologi agar stres partisipan dapat diketahui secara real time dan akurat.

\section{Kepustakaan}

Assef, E. C., Capovilla, A. G., \& Capovilla, F. C. (2007). Computerized Stroop Test to assess selective attention in children with attention deficit hyperactivity disorder. Spanish Journal of Psychology, 10(1), 33-40. doi: 10.1017/S113874160 0006296

Azwar, S. (2015). Penyusunan skala psikologi. Yogyakarta: Pustaka Pelajar.

Brouwer, A., \& Hogervorst, M. A. (2014). A new paradigm to induce mental stress: The Sing-a-Song Stress Test (SSST). Methods Article, 8. doi: 10.3389/fnins. 2014.00224

Burgess, P. W., \& Alderman, N. (2004). Executive dysfunction. Dalam L. H. Goldstein, \& J. E. McNeil, Clinical neuropsychology: A practical guide to assessment and management for clinicians (hal. 185-209). Chichester: John Wiley \& Sons Ltd.

Christ, S. E., White, D. A., Mandernach, T., \& Keys, B. A. (2001). Inhibitory control across the life span. Developmental Neuropsychology, 20(3), 653-669. doi: 10. 1207/S15326942DN2003_7

Diamond, A. (2013). Executive functions. Annual Review of Psychology, 64, 135168. doi: 10.1146/annurev-psych-113 011-143750

Dierolf, A. M., Fechtner, J., Bohnke, R., Wolf, O. T., \& Naumann, E. (2017). Influence of acute stress on response inhibition in healthy men: An ERP study. Psychophysiology, 1-12. doi: 10. 1111 /psyp. 12826 
Echterhoff, G., \& Wolf, O. T. (2012). The stressed eyewitness: The interaction of thematic arousal and post-event stress in memory for central and peripheral event information. Frontiers in Integrative Neuroscience, 6(57), 1-12. doi: 10.3389/fnint.2012.00057

Fancourt, D., Aufegger, L., \& Williamon, A. (2015). Low-stress and high-stress singing have contrasting effects on glucocorticoid response. Frontiers in Psychology, 6(1242), 1-5. doi: 10.3389/ fpsyg.2015.01242

Fancourt, D., Williamon, A., Carvalho, L., Steptoe, A., Dow, R., \& Lewis, I. (2016). Singing modulates mood, stress, cortisol, cytokine and neuropeptide activity in cancer patients and careers. Ecancer, 10(631), 1-13. doi: 10.3332/ ecancer.2016.631

Iverson, G. L., Brooks, B. L., White, T., \& Stern, R. A. (2008). Neuropsychological assessment battery: Introduction and advanced interpretation. Dalam A. M. Horton, \& D. Wedding, The neuropsychology handbook, 3rd edition (hal. 279-343). New York, NY: Springer Publishing Company, LLC.

Karthikeyan, P., Murugappan, M., \& Yaacob, S. (2014). Analysis of Stroop Color Word Test-based human stress detection using electrocardiography and heart rate variability signals. Arabian Journal for Science and Engineering, 39, 1835-1847. doi: 10.1007/s13369-013-0786-8

Kirschbaum, C., Pirke, K., \& Hellhammer, D. H. (1993). The "Trier Social Stress Test" - A tool for investigating psychobiological stress responses in a laboratory setting. Neuropsychobiology, 28, 76-81. doi: 10.1159/000119004
Lazarus, R. S. (1999). Stress and emotion: A new synthesis. New York, NY: Springer Publishing Company, Inc.

Levinson, D. J. (1986). A conception of adult development. American Psychologist, 41(1), 3-13. doi: 10.1037/0003066X.41.1.3

Lyons, D. M., Lopez, J. M., Yang, C., \& Schatzberg, A. F. (2000). Stress-level cortisol treatment impairs inhibitory control of behavior in monkeys. Journal of Neuroscience, 20(20), 78167821. Diambil kembali dari http:// www.jneurosci.org/content/20/20/7816

MacLeod, C. M. (2007). The concept of inhibition in cognition. Dalam D. S. Gorfein, \& C. M. MacLeod, Inhibition in cognition (Vol. xvii, hal. 3-23). Washington, DC: American Psychological Association. doi: 10.1037/11587001

MacLeod, C. M. (2015). The stroop effect. Encyclopedia of Color Science And Technology, 1-6. doi: 10.1007/978-3-64227851-8_67-1

Myers, A., \& Hansen, C. (2002). Experimental psychology (5th ed.). California, CA: Wadsworth Group.

Phillips, R. O. (2015). A review of definitions of fatigue - And a step towards a whole. Transportation Research, Part F 29, 48-56. doi: 10.1016/ j.trf.2015.01.003

Pierce, J. W. (2007). PsychoPy-Psychophysics software in Python. Journal of Neuroscience Methods, 162(1-2), 8-13. doi: 10.1016/ j.jneumeth.2006.11.017

Pilli, R., Naidu, M. U., Pingali, U. R., Shobha, J. C., \& Reddy, A. P. (2013). A Computerized Stroop Test for the evaluation of psychotropic drugs in healthy participants. Indian Journal of Psychological Medicine, 35(2), 180-189. doi: 10.4103/0253-7176.116251 
Renaud, P., \& Blondin, J. P. (1997). The stress of stroop performance: Physiological and emotional responses to color-word interference, task pacing, and pacing speed. International Journal of Psychophysiology, 27(2), 87-97. doi: 10.1016/S0167-8760(97)00049-4

Roos, L. E., Knight, E. L., Beauchamp, K. G., Berkman, E. T., Faraday, K., Hyslop, K., \& Fisher, P. A. (2017). Acute stress impairs inhibitory control based on individual differences in parasympathetic nervous system activity. Biological Psychology, 125, 5863.doi: 10.1016/j.biopsycho.2017.03.004

Schoofs, D., Preuß, D., \& Wolf, O. T. (2008). Psychosocial stress induces working memory impairments in an N-Back paradigm. Psychoneuroendocrinology, 33(5), 643-653. doi: 10.1016/j. psyneuen.2008.02.004

Schwabe, L., Höffken, O., Tegenthoff, M., \& Wolf, O. T. (2013). Stress-induced enhancement of response inhibition depends on mineralocorticoid receptor activation. Psychoneuroendocrinology, 38, 2319-2326. doi: 10.1016/j. psyneuen.2013.05.001
Selye, H. (1974). Stress without distress. Philadelphia, PA; New York, NY: J. B. Lipincott Company.

Stroop, J. R. (1935). Studies of interference in serial verbal reactions. Journal of Experimental Psychology, 18(6), 643-662. doi: 10.1037/h0054651

Utami, M. S. (2010). Skala kesejahteraan subjektif mahasiswa. Laporan hibah penelitian Fakultas Psikologi UGM.

Vitaterna, M. H., Takahashi, J. S., \& Turek, F. W. (2001). Overview of circadian rhythms. Alcohol Research \& Health, 25(2), 85-93. Diambil kembali dari https://www.pubs.niaaa.nih.gov/publi cations/arh25-2/85-93.htm

Watson, D., \& Clark, L. A. (1984). Negative affectivity: The disposition to experience aversive emotional states. Psychological Bulletin, 96(3), 465-490. doi: 10.1037/0033-2909.96.3.465

Watson, D., Clark, L. A., \& Tellegen, A. (1988). Development and validation of brief measures of positive and negative affect: The PANAS scales. Journal of Personality and Social Psychology, 54(6), 1063-1070. doi: 10. 1037/0022-3514.54.6.1063 